\title{
Fimbriae- and flagella-mediated association with and invasion of cultured epithelial cells by Salmonella enteritidis
}

\author{
M. P. Dibb-Fuller, ${ }^{1}$ E. Allen-Vercoe, ${ }^{2}$ C. J. Thorns ${ }^{1}$ and M. J. Woodward ${ }^{1}$ \\ Author for correspondence: M. P. Dibb-Fuller. Tel: +44 1932357 671. Fax: +44 1932357401. \\ e-mail : m.p.dibb-fuller@vla.maff.gov.uk
}

1 Bacteriology Department, Veterinary Laboratories Agency (Weybridge), Addlestone, Surrey KT15 3NB, UK

2 CAMR, Porton Down, Salisbury, Wiltshire SP4 0JG, UK

\begin{abstract}
Salmonella enteritidis expresses flagella and several finely regulated fimbriae, including SEF14, SEF17 and SEF21 (type 1). A panel of mutants was prepared in three strains of $S$. enteritidis to elucidate the role of these surface appendages in the association with and invasion of cultured epithelial cells. In all assays, the naturally occurring regulatory-defective strain $27655 R$ associated with tissue culture cells significantly more than wild-type progenitor strains LA5 and S1400/94. Compared with wild-type strains, SEF14 mutants had no effect on association and invasion, whereas SEF17, SEF21 and aflagellate mutants showed significant reductions in both processes. Histological examination suggested a role for SEF17 in localized, aggregative adherence, which could be specifically blocked by anti-SEF17 sera and purified SEF17 fimbriae. SEF21mediated association was neutralized by mannose and a specific monoclonal antibody, although to observe enhanced association it was necessary for the bacteria to be in fimbriate phase prior to infection. Additionally, aflagellate mutants associated and invaded less than motile bacteria. This study demonstrated the potential for multifactorial association and invasion of epithelial cells which involved SEF17 and SEF21 fimbriae, and flagellamediated motility.
\end{abstract}

Keywords: Salmonella enteritidis, fimbriae, flagella, tissue culture

\section{INTRODUCTION}

Salmonella enteritidis PT4 continues to be a major cause of foodborne infections in the United Kingdom and Europe, with poultry implicated as a major source (Humphrey \& Rowe, 1988). Understanding the virulence mechanisms of bacterial pathogens depends upon the ability to study directly host-bacterial interactions. For Escherichia coli it is considered that adherence to enterocytes is a prerequisite for infection and the adhesive function of certain fimbriae has been described (Parry \& Rooke, 1985). However, for Salmonella spp., the role of fimbriae and flagella is poorly understood, although it is commonly thought that they contribute to bacterial survival and persistence in the host and its environment (Thorns, 1995).

S. enteritidis has been demonstrated to express three morphologically distinct fimbriae and flagella. The

Abbreviation: MSHA, mannose-sensitive haemagglutination.
SEF14 fimbrial structure is $<3 \mathrm{~nm}$ in diameter, is composed of repeating fimbrin subunits $14.3 \mathrm{kDa}$ in size and is unique to certain serotypes in serogroup D, including all strains of $S$. enteritidis and Salmonella dublin (Thorns et al., 1990, 1992). SEF17 are hydrophobic organelles (Collinson et al., 1991) that mediate binding to the tissue matrix fibronectin (Collinson $e t$ al., 1993; Baloda et al., 1988), plasminogen (Sjöbring et al., 1994) and human-contact-phase proteins (Ben-Nasr et al., 1996; Herwald et al., 1998). Type 1 fimbriae are ubiquitous amongst members of the Enterobacteriaciae and mediate mannose-sensitive haemagglutination (MSHA) (Duguid et al., 1966; Müller et al., 1991) with animal erythrocytes. Type 1 fimbriae of S. enteritidis (SEF21) and Salmonella typhimurium have been reported recently to bind to rat gut epithelium (Ewen et al., 1997).

The majority of Enterobacteriaceae elaborate flagella, which are considered to assist the bacterium with directional motility, although their role in the pathogenesis of Salmonella is equivocal. A mutant of $S$. 
typhimurium deficient in both MSHA and motility was reported to be greatly reduced in its ability to invade epithelial cells in vitro and persist in the liver and spleen of orally challenged chicks, whereas mutants defective for the elaboration of either flagella or fimbriae alone showed no significant effect (Lee et al., 1996).

Additionally, S. enteritidis has the genetic potential to elaborate a plasmid-encoded fimbriae (PEF) analogue, harboured by the $S$. enteritidis-associated virulence plasmid (Baumler et al., 1996a) and long polar fimbriae (Baumler \& Heffron 1995; Baumler et al. 1996b). The structure of long polar fimbriae has not been described in S. enteritidis, whereas a serological response to PEF has been reported in vivo (Woodward et al., 1996), although plasmid-free organisms remain fully virulent in chickens (Halavatkar \& Barrow, 1993). Salmonella fimbriae are finely regulated and expression can be modulated in vitro by varying temperature, $\mathrm{pH}$, surface contact (Dibb-Fuller et al., 1997; McDermid et al., 1996; Walker et al., 1999) and available nutrients (Thorns et al., 1992).

The interaction between pathogen and host cells during the onset of disease is a current focus of our research. Specifically, very little is known about the contribution of surface appendages of $S$. enteritidis in colonization of the chick. This report describes, as part of these studies, the use of defined mutants to investigate the individual and collective role of fimbriae and flagella in adherence and invasion of cultured epithelial cells prior to in vivo studies in poultry.

\section{METHODS}

Bacteria. S. enteritidis strains $\$ 1400 / 94$ and LA5 are wild-type strains isolated from natural chicken infections and were obtained from a reference collection at the Veterinary Laboratories Agency (Weybridge) (Addlestone, UK). These strains have been well characterized in in vitro studies (Walker et al., 1999) and in chicken models (Cooper et al., 1990) in this laboratory. Strain 27655R was kindly provided by Professor T. Wadström (Lund University, Sweden) and was originally isolated as a rough $S$. enteritidis from a human patient suffering from gastroenteritis (Baloda et al., 1988). We have reported recently the 'atypical' expression of SEF17 by $27655 \mathrm{R}$ amongst $S$. enteritidis (Dibb-Fuller et al., 1997; Allen-Vercoe et al., 1998). All cultures and mutants derived from these strains were maintained on Dorset's egg slopes at $4{ }^{\circ} \mathrm{C}$.

Cultural conditions. For studying the expression of fimbriae and flagella and their subsequent effect in tissue culture models, bacteria were grown under cultural conditions permissive of elaboration of each appendage. Expression of SEF14, SEF17, SEF21 and flagella has previously been reported (Thorns et al., 1992; Dibb-Fuller et al., 1997; Sojka et al., 1996; Hotani, 1971, respectively) and was induced by growth in Sensitest agar (CM409; Oxoid) for $24 \mathrm{~h}$ at $37^{\circ} \mathrm{C}$, colonization factor antigen (CFA) agar (Evans et al., 1977) for $72 \mathrm{~h}$ at $18{ }^{\circ} \mathrm{C}$, heart infusion broth (HIB) (0038-17-7; Difco) for $48 \mathrm{~h}$ at $37^{\circ} \mathrm{C}$, and nutrient broth (CM1; Oxoid) for 24 h at $37^{\circ} \mathrm{C}$, respectively. All cultures were incubated statically in aerobic environments, unless otherwise stated.

Production of purified reagents and specific antibodies. Purification of SEF17, SEF21 and flagella, and the production of monoclonal and polyclonal antibodies, have been described previously (Collinson et al., 1991; Sojka et al., 1996; Hotani, 1971). Soluble fibronectin and LPS were commercial reagents (F-0895 and L-4774, respectively; Sigma).

Direct binding ELISA. Cultures were grown under conditions permissive of expression of surface appendages. After pelleting by centrifugation at $2500 \mathrm{~g}$ for $10 \mathrm{~min}$, bacteria were resuspended in $0.1 \mathrm{M}$ carbonate buffer $\mathrm{pH} 9.6$ and the suspension adjusted to give an optical density of 1.00 at 540 $\mathrm{nm}$. Suspensions were coated on Microtitre plates (Maxisorb; Nunc), dried overnight at $37^{\circ} \mathrm{C}$ and washed four times in $0 \cdot 1 \mathrm{M}$ PBS $\left(12.85 \mathrm{~g} \mathrm{Na}_{2} \mathrm{HPO}_{4} .2 \mathrm{H}_{2} \mathrm{O} \mathrm{l}^{-1}, 3 \cdot 36 \mathrm{~g} \mathrm{NaH}_{2} \mathrm{PO}_{4} \mathrm{l}^{-1}\right.$,

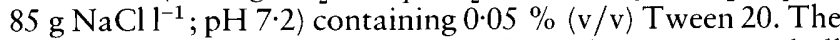
washing step was repeated after each incubation step and all subsequent incubations were performed at $37^{\circ} \mathrm{C}$ for $1 \mathrm{~h}$ except for the substrate, which was performed at room temperature for $5 \mathrm{~min}$. The free binding sites were blocked with $3 \%(\mathrm{w} / \mathrm{v})$ dried milk (Marvel) in PBS $(200 \mu \mathrm{l})$. All other ELISA reagents were added at $100 \mu \mathrm{l}$ per well. mAb was added, followed by goat anti-mouse horseradish-peroxidaseconjugated antibody (Sigma) and then tetramethylbenzidine (TMB; Cambridge Veterinary Sciences) substrate. The reaction was stopped with $10 \%(\mathrm{v} / \mathrm{v})$ sulphuric acid and absorbance recorded at $450 \mathrm{~nm}$.

Construction of mutants. Construction of isogenic mutants of S.enteritidis S1400/94 was described previously (Allen-Vercoe \& Woodward, 1999). Single mutants in strain LA5 and 27655R or multiple mutants were produced by P22 transduction following the methods of Anderson et al. (1996).

Association and invasion assays. Tissue culture cells were maintained in Eagle's Modified Essential Media (EMEM; Sigma) supplemented with $10 \%$ heat-inactivated foetal calf serum (Sigma), $2 \mathrm{mM}$ L-glutamine (Sigma) and $50 \mu \mathrm{g}$ gentamicin (Sigma) $\mathrm{ml}^{-1}$.

Confluent monolayers of human intestinal epithelial cell lines INT-407 and Caco-2 (ECACC; Salisbury) were prepared in 24-well tissue culture plates (Nunc) and pre-washed twice in Hanks' balanced salt solution (HBSS; Sigma) prior to association and invasion assays. Confluent monolayers contained between 4 and $6 \times 10^{5}$ cells per well, and three wells were used for each test. For the association assay, INT-407 cells were infected at a ratio of $1: 100$ with pre-washed bacteria (in EMEM) and incubated for $2 \mathrm{~h}$ at $37^{\circ} \mathrm{C}\left(5 \% \mathrm{CO}_{2}\right)$. Monolayers were washed six times with HBSS before disrupting with $1 \%(v / v)$ Triton (Sigma). C.f.u. were determined by serial dilutions plated onto Brilliant Green agar (CM329; Oxoid). Association is reported as a combination of adhering and invading bacteria.

Invasion assays were performed in duplicate 24-well plates. After allowing the bacteria to associate with the monolayer, wells were washed three times before adding EMEM containing $100 \mu \mathrm{g}$ gentamicin $\mathrm{ml}^{-1}$. Plates were incubated at $37^{\circ} \mathrm{C}$ $\left(5 \% \mathrm{CO}_{2}\right)$ for $2 \mathrm{~h}$ and washed twice. The monolayers were then disrupted with Triton and c.f.u. were determined as described above.

Each association and invasion assay was performed at least twice (three wells per test) and representative results are reported. For statistical analyses, counts were transformed to their logarithm to base 10 , and analyses of variance (ANOVA) performed, followed by standard $F$-tests.

Blocking assays. Mannose, polyclonal antisera $(1 / 100 \mathrm{di}$ lution) and $\mathrm{mAb}\left(1 \mathrm{mg} \mathrm{ml} \mathrm{m}^{-1}\right)$ were added to the bacterial suspension and the purified fimbriae, flagella, LPS and fibronectin added to the tissue culture cells. All reactions were 
incubated for $15 \mathrm{~min}$ at $37{ }^{\circ} \mathrm{C}\left(5 \% \mathrm{CO}_{2}\right)$ with gentle agitation prior to infection of the monolayer. Counts were statistically compared by one-way ANOVA.

Histological staining of infected INT-407 cells. Confluent monolayers prepared in six-well dishes (Bibby) on $18 \mathrm{~mm}$ diameter round coverslips were washed twice in HBSS and infected with $2.5 \times 10^{8}$ bacteria in EMEM $(5 \mathrm{ml})$. After incubating for $2 \mathrm{~h}$ at $37^{\circ} \mathrm{C}\left(5 \% \mathrm{CO}_{2}\right)$, monolayers were washed six times in HBSS, fixed for 10 min with cold methanol $(70 \%)$ and stained with $10 \%$ Giemsa stain (Sigma) for $1 \mathrm{~h}$. Coverslips were washed four times in deionized water and differentiated in $1 \%$ acetic acid $(1 \mathrm{~min})$, washed again, airdried and mounted onto slides with DPX mountant (Sigma). Slides were examined by light microscopy under oil immersion ( $\times 1000$ magnification). Adherent cells were visualized with a Zeiss light microscope (Axiovert 25) equipped with a Contax 167 MT camera.

\section{RESULTS}

\section{Production of single and multiple mutants}

Single defined mutants were prepared in S. enteritidis strain S1400/94 by insertion of antibiotic resistance cassettes within target genes as previously described (Allen-Vercoe \& Woodward, 1999). Construction of single and multiple mutants in strains LA5 and 27655R was made as required by $\mathrm{P} 22$-mediated transduction with selection for the internal marker (Table 1). All transductants were quantitatively assayed for the expression of SEF14, SEF17, SEF21 and flagella by direct binding ELISA (Table 1). Mutants failed to elaborate the appendage encoded by the insertionally inactivated gene. No evidence was gained that mutation of any one locus altered expression of any other surface appendage.

\section{Fimbriae- and flagella-mediated association with and invasion of INT-407 monolayers}

Wild-type and single mutants were assessed for association and invasion in the INT-407 model. In all three strains with the SEF14 mutation there was no significant reduction in association or invasion of tissue culture cells. For all strains, the wild-type associated in greater numbers than the isogenic SEF17 mutants $(P<0 \cdot 001)$, whilst for bacterial invasion the differences were significant for LA5 $(P=0.02)$ and S1400/94 $(P=0.659)$, and highly significant for $27655 \mathrm{R}(P<0 \cdot 001)$. Wild-type associated $(P<0.001)$ and invaded $(P<0.001)$ in significantly higher numbers than the SEF21 mutants in all three strains. Also, aflagellate mutants associated and invaded significantly less $(P<0 \cdot 001)$ than their respective wild-types. In all experiments where it was tested, strain $27655 \mathrm{R}$ associated in significantly greater numbers than LA5 and S1400/94 (Fig. 1a, b, c).

Multiple mutants prepared in LA5 were tested in the INT-407 and Caco-2 models (Fig. 2). Counts following infection of INT-407 with LA5 wild-type were compared statistically with single and multiple mutants using oneway ANOva. Association of the wild-type was significantly higher than all the mutants except for B214 $\left(\mathrm{SEF} 14^{-}\right)$, with the significance probability for EAV12

Table 1. Direct binding ELISA using specific mAbs to determine expression of fimbriae and flagella by single and multiple mutants of $S$. enteritidis when grown under permissive conditions

\begin{tabular}{|c|c|c|c|c|c|c|c|}
\hline \multirow[t]{2}{*}{ Strain } & \multirow{2}{*}{$\begin{array}{l}\text { Reference } \\
\text { name }\end{array}$} & \multirow[t]{2}{*}{ Genotype } & \multirow{2}{*}{$\begin{array}{l}\text { Antibiotic } \\
\text { marker* }\end{array}$} & \multicolumn{4}{|c|}{ Phenotype $\nmid$} \\
\hline & & & & SEF14 & SEF17 & SEF21 & Flagella \\
\hline \multirow[t]{8}{*}{ LA5 } & Wild-type & & & +++ & + & + & ++ \\
\hline & B214 & $\operatorname{sef} A$ & Kan & - & + & + & ++ \\
\hline & EAV12 & $\operatorname{ag} f A$ & Bla & +++ & - & + & ++ \\
\hline & EAV3 & $f i m D$ & Tet & $++t$ & + & - & ++ \\
\hline & EAV10 & $\mathrm{fliC}$ & Cam & +++ & + & + & - \\
\hline & EAV42 & sef $A$ agf $A$ & Kan Bla & - & - & + & ++ \\
\hline & EAV21 & sefA agf $A$ fimD & Kan Bla Tet & - & - & - & ++ \\
\hline & EAV40 & sefA agfA fimD fliC & Kan Bla Tet Cam & - & - & - & - \\
\hline \multirow[t]{5}{*}{ S1400/94 } & Wild-type & & & +++ & + & + & ++ \\
\hline & EAV13 & $\operatorname{sef} A$ & Kan & - & + & + & ++ \\
\hline & EAV11 & $\operatorname{ag} f A$ & Bla & +++ & - & + & ++ \\
\hline & EAV1 & fimD & Tet & +++ & + & - & ++ \\
\hline & EAV9 & $\mathrm{fliC}$ & Cam & +++ & + & + & - \\
\hline \multirow[t]{4}{*}{$27655 \mathrm{R}$} & Wild-type & & & +++ & ++ & + & ++ \\
\hline & EAV28 & sef $A$ & Kan & - & ++ & + & ++ \\
\hline & EAV30 & $\operatorname{ag} f A$ & $\mathrm{Bla}$ & +++ & - & + & ++ \\
\hline & EAV29 & fimD & Tet & +++ & ++ & - & ++ \\
\hline
\end{tabular}

* Kan, kanamycin; Bla, ampicillin; Tet, tetracycline; Cam, chloramphenicol.

$\dagger A_{450}$ in direct binding ELISA :,$+++>1 \cdot 0 ;++,>0 \cdot 5 ;+,>0 \cdot 1 ;-,<0 \cdot 1$. 

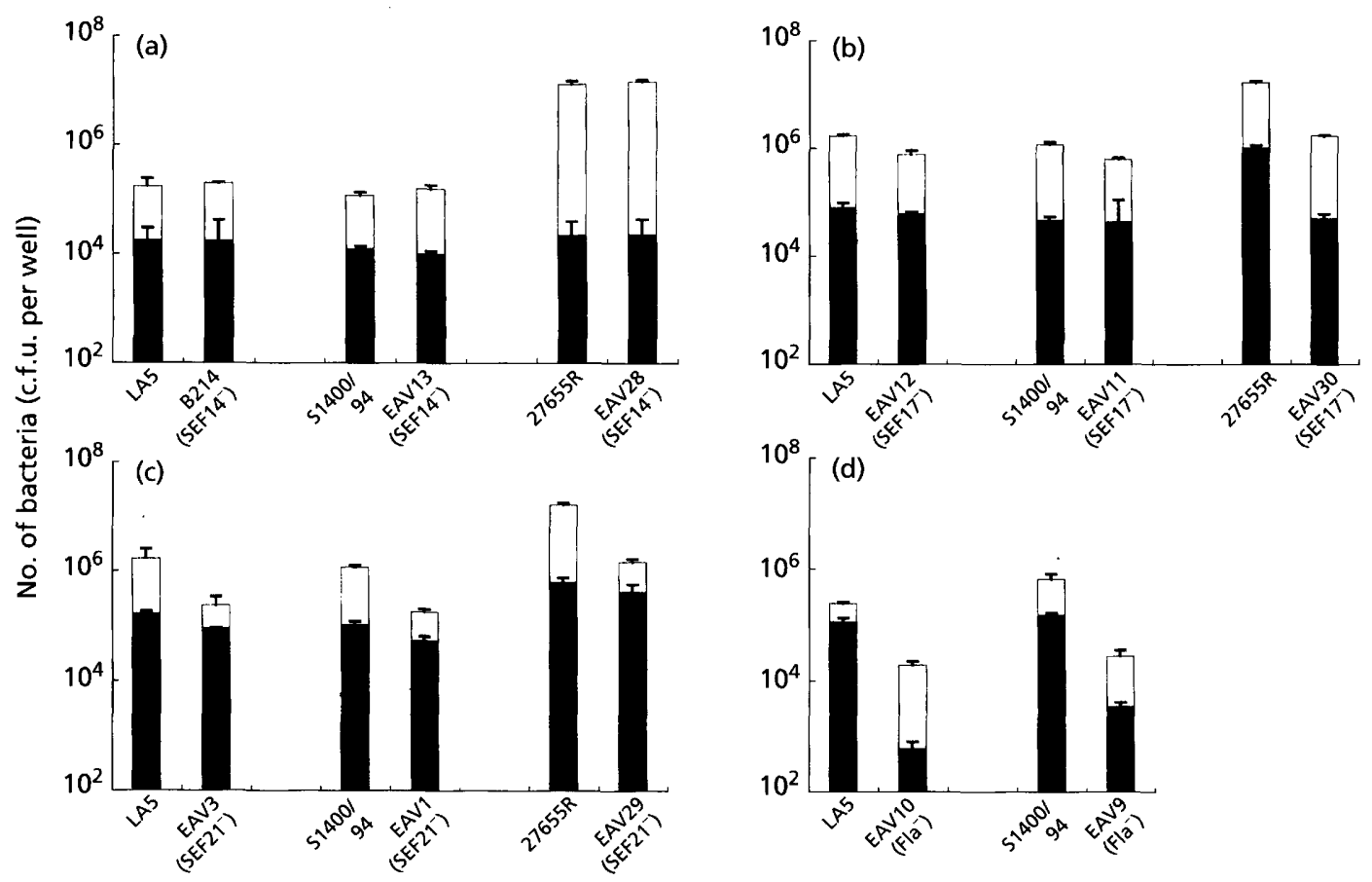

Fig. 1. Association ( $\square$ ) and invasion ( $\square$ ) of INT-407 monolayers by $S$. enteritidis wild-type and single mutants. Bacteria were cultured under conditions permissive for expression of appendages prior to infection of monolayers. Results are expressed as c.f.u. per well \pm SE. (a) SEF14, (b) SEF17, (c) SEF21, (d) flagella.
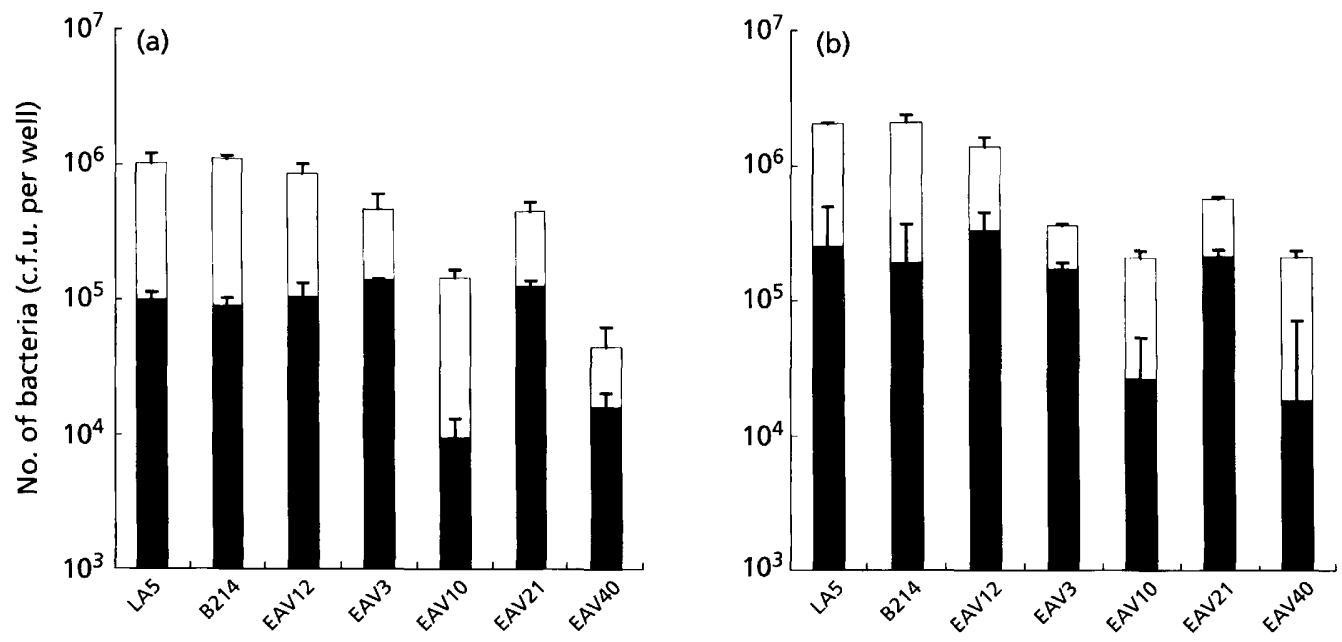

Fig. 2. Association ( $\square$ ) and invasion ( $\square$ ) of INT-407 (a) and Caco-2 (b) monolayers by single and multiple mutants of $S$. enteritidis. Bacteria were cultured in HIB for $48 \mathrm{~h}$ prior to infection of monolayers. Results are expressed as c.f.u. per well \pm SE. LA5, wild-type; B214, SEF14 ${ }^{-}$; EAV12, SEF17- ${ }^{-}$EAV3, SEF21 ${ }^{-}$; EAV10, Fla ${ }^{-}$; EAV21, SEF14- SEF17- SEF21-- EAV40, SEF14- SEF17- SEF21- ${ }^{-}$Fla $^{-}$

(SEF17 ${ }^{-}$) being $P=0.025$ and the remaining differences being $P<0.001$. EAV10 (Fla ${ }^{-}$) and EAV40 (SEF14 ${ }^{-}$ SEF17 $^{-}$SEF$^{-} 1^{-}$Fla $\left.^{-}\right)$exhibited significant reductions in invasion $(P<0.001)$ compared to wild-type.

The trend of association and invasion of single and multiple mutants in Caco-2 cells was very similar to INT-407 (Fig. 2).

\section{Blocking of fimbriae- and flagella-mediated association and invasion}

Purified antigens and specific antibodies were incorporated into the INT -407 model to specifically block the interaction between bacteria and epithelial cells (Table $2 a, b, c)$. The addition of polyclonal antisera and purified SEF17 fimbriae significantly reduced association $(P<$ 
Table 2. Blocking of fimbriae- and flagella-mediated association and invasion of INT-407 monolayers using neutralizing antibodies and purified surface antigens

Results are expressed as c.f.u. per well \pm SE. $* *$, Significant difference from wild-type $(P=0 \cdot 021)$; **; significant difference from wild-type $(P<0.001)$; no asterisks, no significant difference from wild-type.

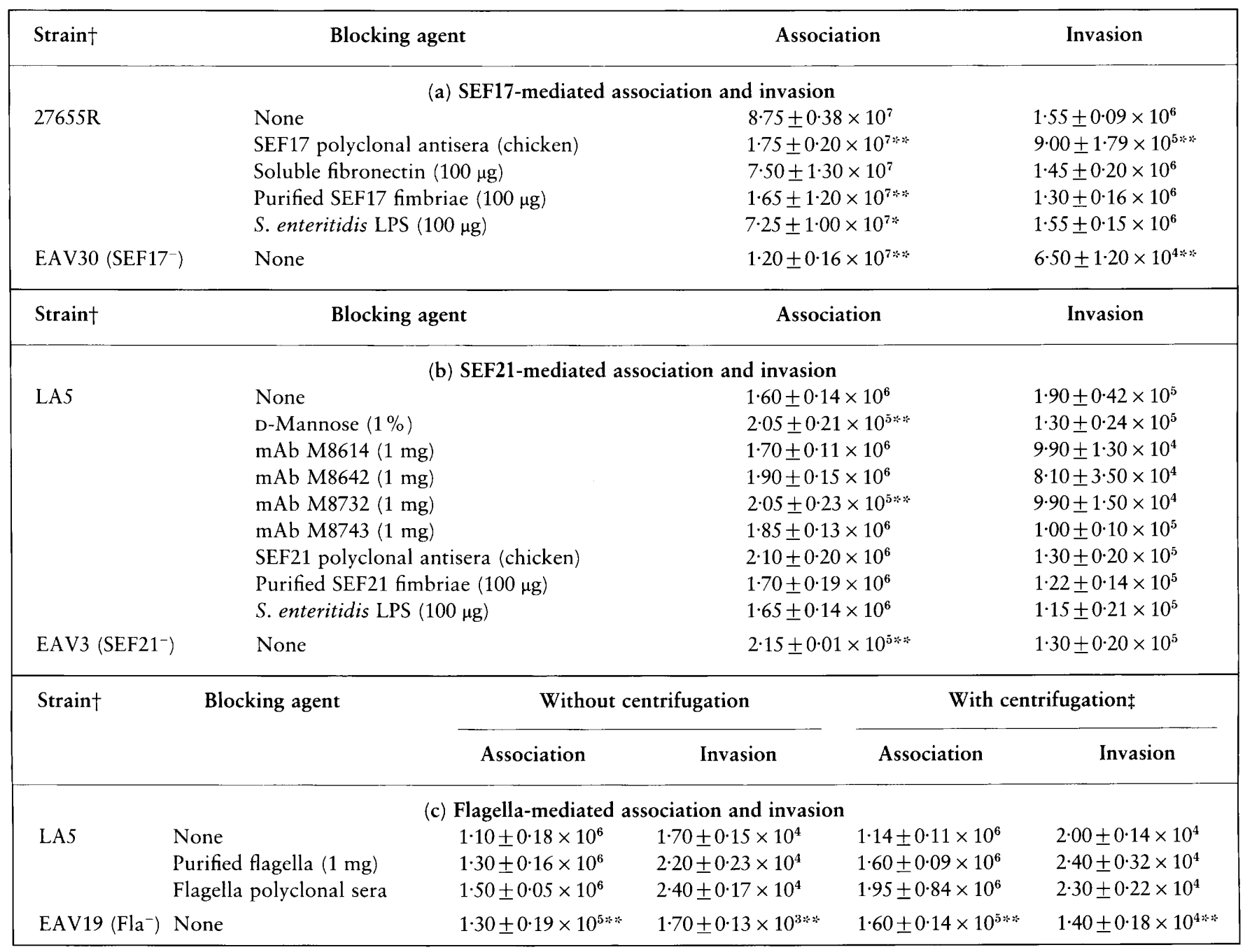

† Bacteria were cultured in CFA agar for $24 \mathrm{~h}$ at $30^{\circ} \mathrm{C}$ (a); in $\mathrm{HIB}$ for $48 \mathrm{~h}$ at $37^{\circ} \mathrm{C}\left(5 \% \mathrm{CO}_{2}\right)(\mathrm{b})$; and in nutrient broth for $24 \mathrm{~h}$ at $37^{\circ} \mathrm{C}$ (c).

$\ddagger$ Bacteria centrifuged onto monolayer at $250 \mathrm{~g}$ for $10 \mathrm{~min}$.

$0 \cdot 001)$ as did LPS, less significantly $(P=0.021)$, but association was unaffected by the addition of soluble fibronectin. Polyclonal sera significantly reduced bacterial invasion $(P<0.001)$, whereas the other treatments had no effect.

SEF21-mediated association was significantly reduced by the addition of D-mannose and $\mathrm{mAb} M 8732(P<$ $0 \cdot 001$ ), whereas invasion was unaffected by any of the reagents added.

Centrifugation of wild-type $S$. enteritidis onto the monolayer increased bacterial association by a small, but highly significant amount $(P<0.001)$ and by two- fold with EAV10 (aflagellate mutant). Also, a significant increase in invasion $(P<0.001)$ was observed after centrifugation of the aflagellate mutant. The addition of purified flagella or polyclonal sera had no effect.

\section{Histological examination of infected monolayers}

Wild-type 27655R adherence was localized and often aggregative (Fig. 3a), whereas wild-type LA5 cultured to express SEF21 colonized the INT-407 cells in a random, diffuse pattern (Fig. 3c). EAV12 (27655R, SEF17 ${ }^{-}$) and EAV3 (LA5, SEF21-) associated visibly less than wildtypes (Fig. $3 \mathrm{~b}$ and d, respectively). 

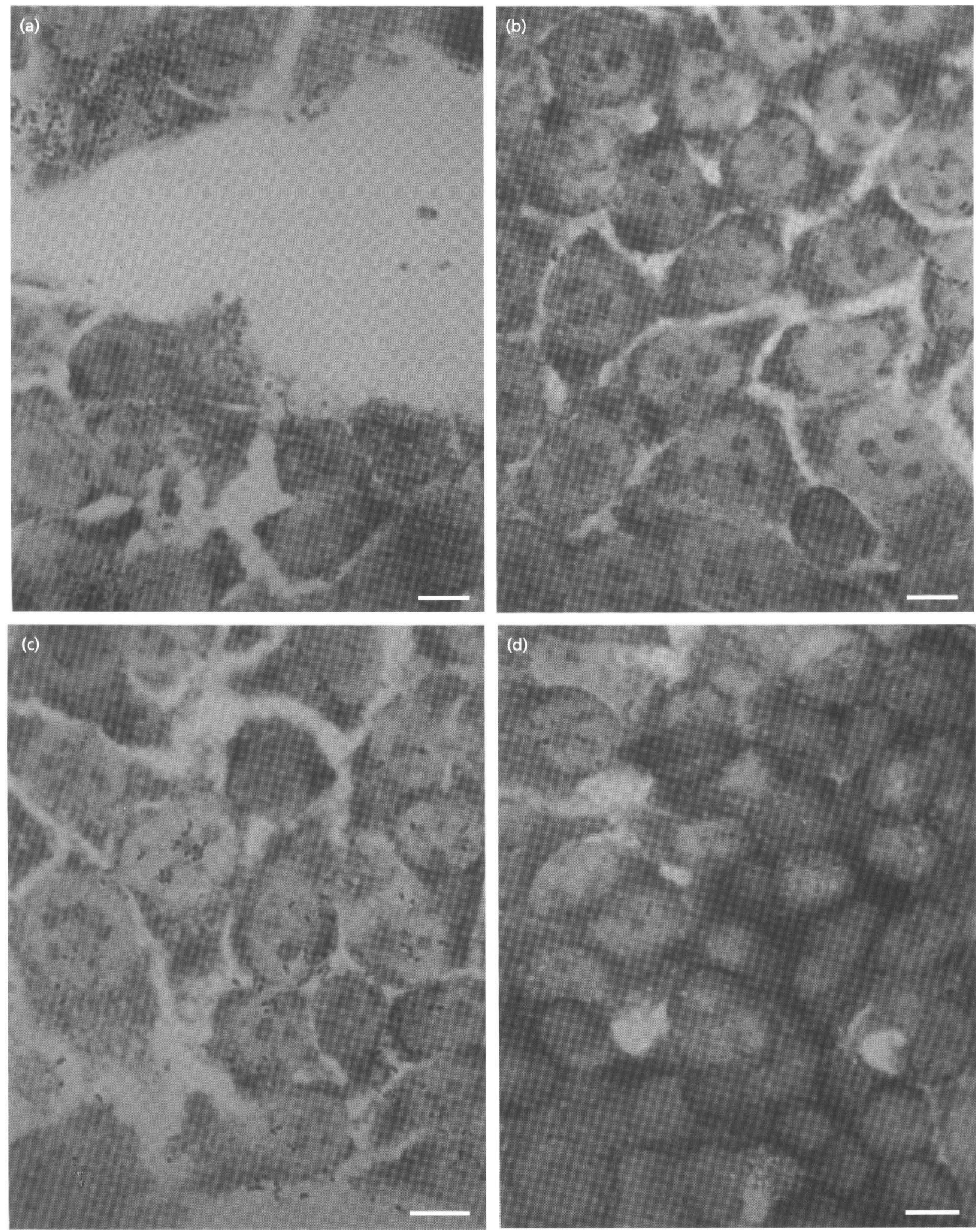

Fig. 3. Adhesion of S. enteritidis to INT-407 cells. 27655R (a) and EAV12 (SEF17) (b) were cultured on CFA agar for $24 \mathrm{~h}$ at $30^{\circ} \mathrm{C}$, and LA5 (c) and EAV3 (SEF $\left.21^{-}\right)$(d) were cultured at $37^{\circ} \mathrm{C}$ in HIB for $48 \mathrm{~h}\left(5 \% \mathrm{CO}_{2}\right)$ before infecting monolayers. Bars, $10 \mu \mathrm{m}$. 


\section{DISCUSSION}

To elucidate the role of fimbriae and flagella in colonization and invasion of transformed human intestinal epithelial cells, a panel of single and multiple mutants was prepared in three strains of $S$. enteritidis by insertional inactivation of target genes. The loss of phenotypic expression was confirmed by direct binding ELISA after culture of mutants under conditions permissive for elaboration of appendages. Expression of the surface appendages encoded by undisrupted genes remained unaffected.

Strain 27655R consistently associated with INT-407 cells significantly more than LA5 and S1400/94 (Fig. 1), which confirmed the findings of Baloda et al. (1988). We have recently reported the 'atypical' expression of SEF17 by 27655R amongst $S$. enteritidis (Dibb-Fuller $e t$ al., 1997), although aberrant elaboration of this fimbrial structure was not attributed to a frameshift mutation in the $r p o S$ global regulatory gene harboured by this strain (Allen-Vercoe et al., 1998). The structural fimbrin subunit of SEF17, AgfA, is genetically and antigenically related to E. coli curli fimbriae (Collinson et al., 1992) and thin aggregative fimbriae of S. typhimurium (Stolpe et al., 1994). Expression of thin aggregative fimbriae of $S$. typhimurium has been demonstrated to promote interaction with mouse small intestinal epithelial cells (Sukupolvi et al., 1997). These results are consistent with the behaviour of $27655 \mathrm{R}$ in our model. Association of the agf $A$ mutant was significantly reduced and histological examination suggested a role for SEF17 in localized, often aggregative adherence, which could be specifically blocked with polyclonal sera or purified fimbriae (Table 2a). SEF17 would appear to promote an extremely aggregative phenotype, but it is unclear whether SEF17 mediated aggregation in the inoculum, although macroscopic clumping in cultures was not observed. An additional role in biofilm formation has been suggested by Austin et al. (1998), which supports the concept that SEF17 mediates aggregation.

Type 1 fimbriae of S. typhimurium and some E. coli are regarded as virulence determinants which play a role in colonization of gut epithelia (Lockman \& Curtiss 1992; Takeuchi, 1967; Vidotto et al., 1997) and invasion (Ernst et al., 1990). However, Elliot \& Kaper (1997) reported that type 1 fimbriae had no effect on levels or patterns of adhesion to cultured human cells in enteropathogenic E. coli (EPEC) infections. Our results suggest SEF21 mediated association in all three strains, although to observe this it was necessary to induce expression of fimbriae prior to infection (Fig. 1). Thus, a correlation was observed between level of association and SEF21 expression in the inoculum as measured by MSHA. These results agree with those of Tavendale $e t$ al. (1983).

SEF14 mutants in all three strains reacted very similarly, with no significant difference in either association or invasion compared to their respective wild-type. These results are consistent with those of Thorns et al. (1996) and Oginniyi et al. (1997). Interestingly, a role for SEF14 in transovarian transmission in chickens has been suggested by Thiagarajan et al. (1996).

Aflagellate mutants of $S$. enteritidis associated and invaded significantly less than motile bacteria, and numbers of associated bacteria were increased only marginally by centrifugation of bacteria onto monolayers. Numbers of associating bacteria were unaffected by the addition of purified flagella or specific polyclonal antibody to the flagellated wild-type. It is highly likely that flagella assist colonization of epithelial cells by enabling motility rather than providing an adhesin. This confirms our earlier work with adherence to chick gut explants (Allen-Vercoe et al., unpublished results). Interestingly, Jones et al. (1992) reported that the direction of flagellar rotation affected the ability of $S$. typhimurium to invade cultured epithelial cells and, in addition, flagella have been implicated in assisting survival of S. typhimurium within murine macrophages (Weinstein et al., 1984).

Characterization of fimbriae- and flagella-mediated interaction with cultured epithelial cells is an initial step in evaluating the role of these surface structures in pathogenesis of $S$. enteritidis. Tissue culture models have limitations for they cannot recreate the gut environment but this study demonstrates the potential role of SEF21 and SEF17 in adherence, and suggests a motility function for flagella in an undoubtedly multifactorial process. The question arises as to whether these observations will prove consistent in studies with chick gut explant models and chick in vivo studies.

\section{ACKNOWLEDGEMENTS}

This work was supported by the Ministry of Agriculture, Fisheries and Food, GB (Project OZ0128) and contributions from E. A.-V. were funded by the Department of Health. We thank Mrs M. Sojka for her advice on purification of antigens, Mr R. Sayers for statistical analyses and Mrs A. Long for tips on histological methods.

\section{REFERENCES}

Allen-Vercoe, E. \& Woodward, M. J. (1999). Adherence of Salmonella enterica serovar Enteritidis to chick gut explant; the role of flagella but not fimbriae. J Med Microbiol (in press).

Allen-Vercoe, E., Collighan, R. \& Woodward, M. J. (1998). The variant rpoS allele of $S$. enteritidis strain 27655R does not affect virulence in the chick model nor constitutive curliation but does generate a cold sensitive phenotype. FEMS Microbiol Lett 167, 245-253.

Anderson, R. J., Londono, L. P., Pickard, D. J. \& Dougan, G. (1996). Development of attenuated Salmonella strains that express heterologous antigens. In Methods in Molecular Medicine: Vaccine Protocols, pp. 47-62. Edited by A. Robinson, G. Farrar \& C. Wiblin. Totowa: Humana Press.

Austin, J. W., Sanders, G., Kay, W. W. \& Collinson, K. (1998). Thin aggregative fimbriae enhance Salmonella enteritidis biofilm formation. FEMS Microbiol Lett 162, 295-301. 
Baloda, S. B., Faris, A. \& Krovacek, D. (1988). Cell surface properties of enterotoxigenic and cytotoxic Salmonella enteritidis and Salmonella typhimurium: studies on haemagglutination, cell surface hydrophobicity, attachment to human intestinal cells and fibronectin binding. Microbiol Immunol 22, 447-459.

Baumler, A. J. \& Heffron, F. (1995). Identification and sequence analysis of $l p f A B C D E$, a putative fimbrial operon of Salmonella typhimurium. J Bacteriol 177, 2087-2097.

Baumler, A. J., Tsoli, R. M., Bowe, F. A., Kusters, J. G., Hoffmann, S. \& Heffron, F. (1996a). The pef operon of Salmonella typhimurium mediates adhesion to murine small intestine and is necessary for fluid accumulation in the infant mouse. Infect Immun 64, 61-68.

Baumler, A. J., Tsoli, R. M. \& Heffron, F. (1996b). The $l p f$ operon mediates adhesion of Salmonella typhimurium to murine Peyer's patches. Proc Natl Acad Sci USA 93, 279-283.

Ben-Nasr, A., Olsen, A., Sjöbring, U., Muller-Esterl, W. \& Bjorck, L. (1996). Assembly of human contact phase proteins and release of bradykinin at the surface of curli-expressing Escherichia coli. Mol Microbiol 20, 927-935.

Collinson, K. S., Emody, L., Muller, K. H., Trust, T. J. \& Kay, W. W. (1991). Purification and characterization of thin aggregative fimbriae from Salmonella enteritidis. J Bacteriol 173, 4773-4781.

Collinson, K. S., Emody, L. K. H., Trust, T. J. \& Kay, W. W. (1992). Thin aggregative fimbriae from diarrhoegenic Escherichia coli. $J$ Bacteriol 174, 4490-4495.

Collinson, K. S., Doig, P. C., Doran, J. L., Clouthier, S., Trust, T. J. \& Kay, W. W. (1993). Thin aggregative fimbriae mediate binding of Salmonella enteritidis to fibronectin. J Bacteriol 175, 12-18.

Cooper, J. L., Nicholas, R. A., Cullen, G. A. \& Hormaeche, L. (1990). Vaccination of chickens with a Salmonella enteritidis aroA, live oral salmonella vaccine. Microb Pathog 9, 255-265.

Dibb-Fuller, M. P., Allen-Vercoe, E., Woodward, M. J. \& Thorns, C. J. (1997). Expression of SEF17 fimbriae by Salmonella enteritidis. Lett Appl Microbiol 25, 447-452.

Duguid, J. P., Anderson, E. \& Campbell, I. (1966). Fimbriae and adhesive properties in Salmonella. J Pathol Bacteriol 92, 107-138.

Elliot, S. J. \& Kaper, J. B. (1997). Role of type 1 fimbriae in EPEC infections. Microb Pathog 23, 113-118.

Ernst, R. K., Dombroski, D. M. \& Merrick, J. M. (1990). Anaerobiosis, type 1 fimbriae, and growth phase are factors that affect invasion of Hep-2 cells by Salmonella typhimurium. Infect Immun 58, 2014-2016.

Evans, D. G., Evans, D. J. \& Tjoa, W. (1977). Hemagglutination of ' human group A erythrocytes by enterotoxigenic Escherichia coli isolated from adults with diarrhea: correlation with colonization factor. Infect Immun 18, 330-337.

Ewen, S. W. B., Naughton, P. J., Grant, G., Sojka, M., AllenVercoe, E., Bardoocz, S., Thorns, C. J. \& Pusztai, A. (1997). Salmonella enterica var. Typhimurium and Salmonella enterica var. Enteritidis express type 1 fimbriae in the rat in vivo. FEMS Immunol Med Microbiol 18, 185-192.

Halavatkar, H. \& Barrow, P. A. (1993). The role of the 54-kb plasmid in the virulence of strains of Salmonellla enteritidis of phage type 4 for chicken and mice. J Med Microbiol 38, 171-176.

Herwald, H., Morgelin, M., Olsen, A., Rhen, M., Dahlback, B., Muller-Esterl, W. \& Bjorck, L. (1998). Activation of the contactphase system on bacterial surfaces - a clue to serious complications in infectious diseases. Nature Med 4, 298-302.

Hotani, H. (1971). Interconversion between flagella and P-filament in vitro. J Mol Biol 57, 575-587.
Humphrey, T. J. \& Rowe, B. (1988). Poultry meat as a source of human salmonellosis in England and Wales. Epidemiol Infect 100, 175-184.

Jones, B. D., Lee, C. A. \& Falkow, S. (1992). Invasion by Salmonella typhimurium is affected by the direction of flagellar rotation. Infect Immun 60, 2475-2480.

Lee, M. D., Curtiss, R., III \& Peay, T. (1996). The effect of bacterial surface structures on the pathogenesis of Salmonella typhimurium infection in chickens. Avian Dis 40, 28-36.

Lockman, H. A. \& Curtiss, R. (1992). Isolation and characterisation of conditionally adherent and non-type 1 fimbriated Salmonella typhimurium mutants. Mol Microbiol 6, 933-945.

McDermid, A. S., Mckee, A. S., Dowsett, A. B. \& Marsh, P. D. (1996). The effect of environmental $\mathrm{pH}$ on the physiology and surface structures of Salmonella serotype Enteritidis phage type 4. J Med Microbiol 45, 452-458.

Müller, K. H., Collinson, K. S., Trust, T. J. \& Kay, W. W. (1991). Type 1 fimbriae of Salmonella. J Bacteriol 173, 4765-4772.

Ogunniyi, A. D., Kotlarski, I., Morona, R. \& Manning, P. A. (1997). Role of SefA subunit protein of SEF14 fimbriae in the pathogenesis of Salmonella enterica serovar Enteritidis. Infect Immun $\mathbf{6 5}$, 708-717.

Parry, S. H. \& Rooke, D. M. (1985). Adhesins and colonisation factors of Escherichia coli. In The Virulence Markers of Escherichia coli, pp. 79-155. Edited by M. Sussman. London: Academic Press.

Sjöbring, U., Pohl, G. \& Olsen, A. (1994). Plasminogen, absorbed by Escherichia coli expressing curli or by Salmonella enteritidis expressing thin aggregative fimbriae, can be activated by simultaneously captured tissue-type plasminogen activator (t-PA). Mol Microbiol 14, 443-452.

Sojka, M. G., Dibb-Fuller, M. P. \& Thorns, C. J. (1996). Characterisation of monoclonal antibodies specific to SEF 21 fimbriae of Salmonella enteritidis and their reactivity with other salmonellae and enterobacteria. Vet Microbiol 48, 207-221.

Stolpe, H., Grund, S. \& Schroder, W. (1994). Purification and partial characterisation of type 3 fimbriae of Salmonella typhimurium var. copenhagen. Zentbl Bakteriol 281, 8-15.

Sukupolvi, S., Lorenz, R. G., Gordon, J. I., Bian, Z., Pfeifer, J. D., Normark, S. J. \& Rhen, M. (1997). Expression of thin aggregative fimbriae promotes interaction of Salmonella typhimurium SR-11 with mouse small intestinal epithelial cells. Infect Immun 65, $5320-5325$.

Takeuchi, A. (1967). Electron microscopy studies of experimental Salmonella infections. Am J Pathol 50, 109-136.

Tavendale, A., Jardine, C. K. H., Old, D. C. \& Duguid, J. P. (1983). Haemagglutinins and adhesion of Salmonella typhimurium to HEp2 and HeLa cells. J Med Microbiol 16, 371-380.

Thiagarajan, D., Saeed, M., Turek, J. \& Asem, E. (1996). In vitro attachment and invasion of chicken ovarian granulosa cells by Salmonella enteritidis phage type 8. Infect Immun 64, 5015-5021. Thorns, C. J. (1995). Salmonella fimbriae: novel antigens in the detection and control of Salmonella infections. $\mathrm{Br}$ Vet $J 151$, 643-658.

Thorns, C. J., Sojka, M. G. \& Chassey, D. (1990). Detection of a novel fimbrial structure on the surface of Salmonella enteritidis by using a monoclonal antibody. J Clin Microbiol 28, 2409-2414.

Thorns, C. J., Sojka, M. G., McLaren, I. M. \& Dibb-Fuller, M. P. (1992). Characterisation of monoclonal antibodies against a fimbrial structure of Salmonella enteritidis and certain other serogroup D salmonellae and their application as serotyping reagents. Res Vet Sci 53, 300-308. 
Thorns, C. J., Turcotte, C., Gemmell, C. G. \& Woodward, M. J. (1996). Studies into the role of the SEF14 fimbrial antigen in the pathogenesis of Salmonella enteritidis. Microb Pathog 20, 1-12.

Walker, S. L., Sojka, M., Dibb-Fuller, M. P. \& Woodward, M. J. (1999). The effect of $\mathrm{pH}$, temperature and surface contact on the elaboration of fimbriae and flagella by Salmonella enteritidis. $J$ Med Microbiol 48, 1-9.

Weinstein, D. L., Carsiotis, M., Lissner, R. \& O'Brien, A. D. (1984). Flagella help Salmonella typhimurium survive within murine macrophages. Infect Immun 46, 819-825.
Woodward, M. J., Allen-Vercoe, E. \& Redstone, J. S. (1996). Distribution, gene sequence and expression in vivo of the plasmid encoded fimbrial antigen of Salmonella serotype Enteritidis. Epidemiol Infect 117, 17-28.

Vidotto, M. C., Navarro, H. R. \& Gaviri, L. C. J. (1997). Adherence of pathogenic strains of avian Escherichia coli. Vet Microbiol $\mathbf{5 9}$ $79-87$.

Received 29 September 1998; revised 24 November 1998; accepted 4 January 1999. 